UDK 341.123.043

Biblid 0543-3657, 71 (2020)

God. LXXI, br. 1179-80, str. 178-199

pregledni članak

Primljen: 21.7.2020.

doi: https://doi.org/10.18485/iipe_mp.2020.71.1179_80.9

\author{
Ljubomir TINTOR
}

\title{
Reforma metoda rada Saveta bezbednosti Ujedinjenih nacija
}

\begin{abstract}
SAŽETAK
$\mathrm{U}$ ovom radu autor se bavi pitanjem reforme metoda rada Saveta bezbednosti, smatrajući ga ključnim segmentom reforme ovog organa Ujedinjenih nacija. Koristeći analitički metod autor sagledava sledeća pitanja koja smatra krucijalnim za efikasnu reformu: upotreba veta u radu Saveta bezbednosti, neformalni oblici sastanaka u okviru Saveta bezbednosti, značaj godišnjih izveštaja koje Savet bezbednosti podnosi Generalnoj skupštini UN, doprinos poseta posmatračkih misija i ključni problemi mirovnih misija Saveta bezbednosti. Cilj rada je da se sagleda dosadašnji tok reforme, uoče određeni nedostaci, te ukaže na moguće pravce promena metoda rada Saveta bezbednosti, kako bi u skorije vreme ovaj glavni organ Ujedinjenih nacija mogao adekvatno da odgovori na buduće izazove.
\end{abstract}

Ključne reči: Ujedinjene nacije, Savet bezbednosti, reforma metoda rada Saveta bezbednosti.

\section{Uvod}

Nakon nedavnih međunarodnih kriza na području Sirije, Libije i Ukrajine postaje očito da Ujedinjene nacije nisu sposobne da ispune osnovni zadatak osnivanja, a to je održavanje međunarodnog mira i bezbednosti. Zbog toga se javljaju sve češći zahtevi za sveobuhvatnom reformom svih organa UN. Usled komplikovanog postupka izmene Povelje UN neophodna je značajna

${ }^{1}$ Autor je doktorand na Pravnom fakultetu Univerziteta u Beogradu, e-mail: ljubomir.tintor@yahoo.com 
politička volja. ${ }^{2}$ Prema stavovima stručne javnosti volja za uspešnu reformu UN može doći od strane stalnih članica Saveta bezbednosti (SB), potrebne većine država u Generalnoj skupštini ili spolja od strane uticajnih međunarodnih organizacija. ${ }^{3}$ Takođe, smatra se da bi za uspešnu reformu UN, pre svega, trebalo pristupiti reformi Saveta bezbednosti kao glavnog organa. ${ }^{4}$

Opravdanje za reformu SB može se pronaći i u činjenici da, za razliku od odluka koje donosi Generalna skupština, odluke Saveta bezbednosti rezolucije - su obavezujuće za sve države članice. ${ }^{5}$ To znači da Savet bezbednosti ima široka ovlašćenja i sledstveno tome može, ako je potrebno, preduzeti razne akcije za očuvanje međunarodnog mira, kao što su npr. uvođenje sankcija koje zadiru u državni suverenitet, ili preduzimanje kolektivne akcije. S obzirom na zadatak koji je postavljen pred Savetom bezbednosti potpuno je opravdano da ovaj organ ima veoma široka ovlašćenja, međutim, problem nastaje kada se postavi pitanje legitimnosti SB. Jedan od osnovnih problema je da se najvažnije odluke u SB donose na osnovu međusobnih konsultacija stalnih članica, a druge članice pri tome ostaju u mraku bez relevantnih informacija neophodnih za donošenje odluka. Iz tog razloga, najveći broj predloga reforme Saveta bezbednosti uglavnom su okrenuti ka povećanju broja članica Saveta bezbednosti, kako stalnih tako i nestalnih zbog veće reprezentativnosti, pritom potpuno zanemarujući druge aspekte reforme koji su možda i značajniji.

S obzirom na trenutne međunarodne odnose, postoji opšte uverenje da je teško očekivati da u skorije vreme dođe do sveobuhvatne reforme Saveta bezbednosti, ali su reforme u pojedinim oblastima, poput reforme metoda rada, svakako izvodljive. ${ }^{6}$

Kada govorimo o potrebi reforme metoda rada Saveta bezbednosti UN kroz istoriju, možemo uočiti tri perioda pojačanog interesovanja za reformu. Prvi period obuhvata period od sredine devedesetih godina prošlog veka do početka novog milenijuma. Drugu fazu možemo uočiti nakon ishoda Svetskog samita održanog 2005. godine. ${ }^{7}$ Nakon toga bilo je primetno da je interesovanje

\footnotetext{
${ }^{2}$ Izmene Povelje UN se smatraju usvojenim kada ih usvoje dve trećine članica Generalne skupštine uključujući i sve stalne članice Saveta bezbednosti. "UN Charter (1945)“, Article 108, General Assembly of United Nations, 24 October 1945.

${ }^{3}$ Nora Gordon, Pathways to Security Council Reform, Center on International Cooperation, New York, 2014, pp. 6-7.

${ }^{4}$ Ibid., pp. 3-4.

${ }^{5}$ Boris Krivokapić, Međunarodno javno pravo, Institut za uporedno pravo, Poslovni i pravni fakultet, Beograd, 2017, str. 810.

${ }^{6}$ Nora Gordon, Pathways to Security Council Reform, op. cit., p. 10.

${ }^{7}$ Joanna Harrington, "The Working Methods of the United Nations Security Council: Maintaining the Implementation of Change", International and Comparative Law Quarterly 66, No. 1, 2017, p. 40.
} 
za reformu metoda rada SB znatno opalo, međutim nakon osnivanja grupe „Otvorenost, koherentnost i transparentnost" može se uočiti treći period pojačane zainteresovanosti koji traje od 2013. godine do danas. ${ }^{8}$ Reformom bi se trebalo postići povećanje transparentnosti rada, smanjenje tajnosti podataka i povećanje saradnje sa državama članicama Ujedinjenih nacija. ${ }^{9}$

Cilj ovog rada biće da razmotri sve ključne elemente reforme metoda rada Saveta bezbednosti koji obuhvataju pitanje upotrebe veta na sednicama Saveta bezbednosti, neformalne sastanke SB, godišnje izveštaje o radu koje je ovaj organ, prema Povelji UN, dužan da podnosi Generalnoj skupštini. Na kraju, biće razmotren značaj posmatračkih i mirovnih misija koje Savet bezbednosti šalje na mesta gde je ugrožen međunarodni mir i međunarodna bezbednost kao posebnog oblika radnog metoda SB. U članku će biti analizirani dosadašnji tok reforme metoda rada Saveta bezbednosti, uočeni nedostaci, sagledani dosadašnji predlozi i biće ponuđena neka nova rešenja za poboljšanje metoda rada kao ključnog segmenta reforme glavnog organa Ujedinjenih nacija.

\section{Pitanje upotrebe veta u radu Saveta bezbednosti}

Primarna nadležnost Saveta bezbednosti ogleda se $\mathrm{u}$ održavanju međunarodnog mira i bezbednosti. Savet bezbednosti, zadužen za kolektivnu bezbednost, obavezan je da ispita svaku situaciju koja može da ugrozi međunarodni mir i predloži mere za prevazilaženje ovih sporova. Iako prema Povelji UN nije predviđeno pravo veta, ono je nastalo ekstenzivnim tumačenjem člana 27 Povelje UN. Pravo veta omogućava stalnim članicama SB da svojim negativnim glasom spreče donošenje odluke o suštinskom pitanju kada sve ostale države glasaju potvrdno. ${ }^{10}$ Opisani način glasanja omogućava stalnim članicama pluralni glas koji pored prava odlučivanja omogućava i pravo sprečavanja donošenja odluka. ${ }^{11}$ Ova privilegija koja je omogućena stalnim članicama SB često usled suprotstavljenih stavova ovih država dovodi do paralisanja u radu Saveta bezbednosti, što je prouzrokovalo da SB selektivno reaguje na međunarodne

${ }^{8}$ Grupa „Otvorenost, koherentnost i transparentnost" je višeregionalna grupa sačinjena od 27 malih i srednjih zemalja, osnovana u maju 2013. godine s ciljem poboljšanja odgovornosti i transparentnosti u Savetu bezbednosti UN.

${ }^{9}$ Eduardo Vargas Toro, UN Security Council Reform: Unrealistic Proposals and Viable Reform Options, American Diplomacy November 25, 2008. Internet: https:/ /www.global policy.org/security-council/security-council-reform/transparency-including-workingmethods-and-decisionmaking-process/41138.html?itemid=914,13/07/2020.

${ }^{10}$ Duško Dimitrijević, Reforma Saveta bezbednosti Ujedinjenih nacija, Institut za međunarodnu politiku i privredu, Brograd, 2009, str. 20.

$180{ }^{11}$ Ibid., str. 21. 
sukobe, pa je nemoguće uspostaviti efikasan sistem kolektivne bezbednosti. Tako je u određenim sukobima Savet bezbednosti vrlo involviran, dok je $\mathrm{u}$ drugim značajnim sukobima SB marginalizovan jer stalne članice ne žele da intervenišu.$^{12} \mathrm{Zbog}$ česte upotrebe veta nije moguće uspostaviti mirovne misije koje bi adekvatno odgovorile na međunarodni konflikt. Iz tog razloga države pribegavaju drugim sredstvima da bi rešile situacije koje zahtevaju odgovor međunarodne zajednice. Ova inertnost u delovanju SB dovodi do smanjenja poverenja u UN, pa države primenjuju unilateralne operacije pod okriljem "doktrine Odgovornost" da se zaštiti. U prilog ovoj tezi govore primeri poput sukoba u Ukrajini, zatim odsustvo reakcije SB na napad hemijskim oružjem koji se dogodio u Siriji. ${ }^{13}$ Takođe pretnja upotrebe veta stalnih članica onemogućava rešenje izraelsko-palestinskog sukoba i konflikta na Kosovu. ${ }^{14}$

Iz tog razloga je još 1950. godine državni sekretar SAD Din Ačeson (Dean Acheson) inicirao zapadno orijentisanoj Generalnoj skupštini usvajanje rezolucije „Ujedinjeni za mir" ${ }^{15}$ Neposredan povod za donošenje rezolucije bio je napad Severne Koreje na Južnu Koreju 1950. godine. Rezolucija je predviđala da u ovakvim situacijama Generalna skupština razmotri situaciju i donese odgovarajuće preporuke članovima UN-a za preduzimanje kolektivnih mera. ${ }^{16}$

Uviđajući problem prečeste upotrebe veta koja koči i usporava rad Saveta bezbednosti, tokom 2013. godine od ministra inostranih poslova Francuske Iber Vedrina (Hubert Védrine) potekla je inicijativa pod nazivom "Novi kodeks ponašanja" koja je ubrzo dobila podršku Ukrajine i Meksika. ${ }^{17}$ Ideja ove inicijative je $\mathrm{u}$ tome da se stalnim članicama Saveta bezbednosti ograniči ulaganje veta kada se razmatraju situacije u kojima se dešavaju zločini protiv čovečnosti, što prouzrokuje bitne povrede ljudskih prava. Danas 114 država u Generalnoj skupštini podržava inicijativu Francuske, čije bi usvajanje značajno reformisalo rad Saveta bezbednosti i omogućilo brže delovanje u

${ }^{12}$ Georgia Papalia, "A Critique of the Unqualified Veto Power", Perth International Law, no. 2, Chicago, 2017, pp. 59-60.

${ }^{13} \mathrm{Ibid}$.

${ }^{14}$ Ibid.

${ }^{15}$ Jochen Prantl, Jean E. Krasno, Informal groups of Memeber states, in: Jean E. Krasno (ed.), The United Nations: Confronting the Challenges of a Global Society, Lynne Reiner Publishers, London, 2004, p. 318.

${ }^{16}$ Treba istaći da se rezolucija Ujedinjeni za mir primenjuje samo na agresiju kao najveći stepen opasnosti po mir. Prvi slučaj primene bio je na zahtev Jugoslavije 1956. godine prilikom trojne agresije na Egipat.

${ }^{17}$ Alexei Timofeitchev, Conseil de sécurité de l'Onu:le droit de véto entre passé et avenir, 29 SEPT. 2015, Internet: https:/ / fr.rbth.com/international/2015/09/29/conseil-desecurite-de-lonu-le-droit-de-veto-entre-pase-et-avenir_443869, 11/06/2020. 
kriznim situacijama. Rusija se žestoko protivi ovoj inicijativi, tako da je malo verovatno da će ona u dogledno vreme biti usvojena. ${ }^{18}$

Pored ove inicijative značajno je spomenuti i druge inicijative koje su se pojavile tokom razmatranja pitanja reforme modela odlučivanja u Savetu bezbednosti u slučaju održavanja međunarodnog mira i bezbednosti. Prvenstveno treba imati $\mathrm{u}$ vidu inicijativu država okupljenih u grupi „Otvorenost, koherentnost i transparentnost“ 2015. godine. ${ }^{19}$ Inicijativa ove grupe država zasniva se na ideji da sve članice UN treba da pruže neophodnu pomoć Savetu bezbednosti pri održavanju i uspostavljanju međunarodnog mira. Posebno se naglašava potreba da se stalne članice Saveta bezbednosti uzdrže od upotrebe veta prilikom donošenja rezolucija čiji je cilj da se spreče situacije koje dovode do ozbiljnog kršenja ljudskih prava i humanitarnih kriza. ${ }^{20}$ Ova grupa je pozvala da se stalne članice Saveta bezbednosti pismeno obavežu na poštovanje odredbi predviđenih inicijativom. Trenutno ovu inicijativu podržava 56 država, uključujući i dve stalne članice Francusku i Veliku Britaniju. ${ }^{21}$

Sličnu inicijativu o ograničenju prava veta podnela je i grupa „Stariji“. ${ }^{22}$ Tokom debata o upotrebi veta $\mathrm{u}$ Savetu bezbednosti pojavili su se vrlo interesantni predlozi koje vredi napomenuti. Prema čileanskom predlogu stalne članice Saveta bezbednosti trebalo bi da se odreknu prava veta postepeno do 2030. godine. ${ }^{23}$ Stav Urugvaja je da bi upotreba veta bila dozvoljena samo u tačno definisanim situacijama. Ova država je iznela veoma zanimljiv predlog da se efekat veta može suspendovati ako Generalna skupština donese takvu odluku. ${ }^{24}$ Pojavio se i stav da se pravo upotrebe veta onemogući kada se razmatraju pitanja iz Glave VII Povelje UN. ${ }^{25}$ Ova promena bi dovela do smanjenja upotrebe veta, ali je pitanje $u$ kojoj meri.

${ }^{18}$ Sputnjik Srbija, Atak na rusko pravo veta u UN 114 država ,za', Internet, https:/ / rslat.sputniknews.com/rusija/201709231112769066-Veto-Rusija, 11/06/2020.

${ }^{19}$ The Accountability, Coherence and Transparency Group, Better Working Methods for today's UN Security Council. Presentation of the ACT, Internet: https://center forunreform.org/sites/default/files/Invitation \%20Launch $\% 20$ ACT $\% 20$ - $\% 202 \%$ 20May\%202013\%20-\%20Civil\%20society, 12/06/2020.

${ }^{20}$ Security council, The veto, Internet: https://www.securitycouncilreport.org/atf/cf/ \%7B65BFCF9B-6D27-4E9C-8CD3-CF6E4FF96FF9\%7D/research_report_3_the _veto_2015.pdf, 12/6/2020.p. 5.

${ }^{21}$ Ibid.

${ }^{22}$ Grupa "Stariji” predstavlja inicijativu svetskih lidera, nezavisnu po svom delovanju, koja se zalaže za razvoj mira, ljudskih prava i univerzalnih vrednosti čovečanstva. Osnovao ju je Nelson Mendela (Nelson Rolihlahla Mandela).

${ }^{23}$ Duško Dimitrijević, Reforma Saveta bezbednosti Ujedinjenih nacija, op. cit., str. 208.

${ }^{24}$ Ibid.

${ }^{25}$ Security council, The veto, op. cit., pp. 6-7. 
Prvenstveno iz razloga što države i danas na određena pitanja primetno glasaju u takozvanim blokovima. Primetno je da po mnogim pitanjima zapadnoevropske države Francuska i Velika Britanija pri glasanju slede volju SAD. Sa druge strane, isto tako primetna je tendencija da Rusija i Kina u poslednje vreme zajedno ulažu veto i imaju vrlo slične interese. ${ }^{26} \mathrm{Iz}$ tog razloga je vrlo diskutabilno da li bi ova reforma donela značajne promene.

Problemi u radu Saveta bezbednosti javljaju se i kada se postavi pitanje da li je pitanje o kojem se odlučuje proceduralno ili suštinsko pitanje. Ovo pitanje je značajno, jer ukoliko se u SB odlučuje o suštinskom pitanju za usvajanje odluke je neophodno devet pozitivnih glasova, uključujući pozitivne glasove svih stalnih članica, dok, ako se radi o proceduralnom pitanju za donošenje odluke je neophodno devet pozitivnih glasova bilo kojih članica SB. ${ }^{27}$ Prema Povelji UN svaka članica može pre odlučivanja zahtevati da se odluči da li je pitanje koje je na dnevnom redu proceduralnog ili suštinskog karaktera. Prilikom ovog odlučivanja stalne članice imaju pravo veta što je stvorilo problem upotrebe dvostrukog veta $u$ radu SB. ${ }^{28}$ Stalne članice SB obilato koristeći prava koja su im omogućena preširokim tumačenjem Povelje UN često unapred najavljuju upotrebu veta, te na taj način neka značajna pitanja uopšte i ne dođu na dnevni red sednica Saveta bezbednosti. Ovaj problem je naročito eskalirao u periodu Hladnog rata, a pokušano je da se reši usvajanjem Rezolucije br. 267(III) 1949. godine..$^{29} \mathrm{U}$ Rezoluciji br. 267 (III) Generalna skupština poziva Savet bezbednosti da tačno određena pitanja koja su navedena $\mathrm{u}$ aneksu razmatraju kao proceduralna. Pre svega, u Rezoluciji se navodi kao proceduralno pitanje osnivanje pomoćnih organa koje Savet bezbednosti smatra neophodnim za vršenje svojih funkcija, zatim održavanje sastanaka van sedišta UN. Podnošenje Generalnoj skupštini zahteva da odluči o merama za održanje međunarodnog mira i bezbednosti kada Savet bezbednosti nije u stanju. ${ }^{30}$

Iako je Generalna skupština donela ovu Rezoluciju stalne članice Saveta bezbednosti nastavile su da shodno sopstvenom nahođenju, rukovodeći se svojim političkim interesima, odlučuju da li je određeno pitanje suštinskog ili proceduralnog karaktera, što vrlo često dovodi do problema da SB ne

${ }^{26}$ Security Council, Veto, Internet: https://www.securitycouncilreport.org/atf/cf/\% 7B65BFCF9B-6D27-4E9C-8CD3-CF6E4FF96FF9\%7D/working_methods_veto.pdf, 12/ 06/2020. pp. 1-20.

${ }^{27}$ Izuzetak od ovakvog načina glasanja u SB javlja se prilikom izbora sudija Međunarodnog suda pravde kada je za izbor dovoljna prosta većina. Duško Dimitrijević, Reforma Saveta bezbednosti Ujedinjenih nacija, op. cit., str. 22-23.

${ }^{28}$ Ibid.

29 “Resolution 267(III) (1949)”, General Assembly of United Nations, 14. April 1949.

${ }^{30}$ Security council, UN Security Council Working Methods, https://www.securitycouncil report.org/un-security-council-working-methods/procedural-vote.php, 12/06/2020. 
reaguje adekvatno na međunarodne sukobe. Problem dvostrukog veta doveo je u savremenom sistemu kolektivne bezbednosti do kraha delovanja SB prilikom pokušaja sprečavanja sukoba poput onih u Darfuru i Ruandi. ${ }^{31}$ Ipak, vremenom se uobičajila praksa da se na određena pitanja prilikom rada Saveta bezbednosti posmatra kao na proceduralna pitanja, na primer sadržaj dnevnog reda zasedanja. Međutim, u stručnoj literaturi i dalje preovladava stav da konkretno rešenje za sada nije moguće, jer pitanje nije postavljeno na jasnim pravnim osnovama. ${ }^{32} \mathrm{U}$ praksi je evidentna pravna nesigurnost, naročito ako se ima $u$ vidu da nijedan organ UN nema moć da tumači i nameće svoj stav o dometima Povelje UN, stoga se u stručnoj literaturi mogu pronaći stavovi da SB uopšte ne bi trebao da dođe u poziciju da odlučuje o tome da li je neko pitanje suštinskog ili proceduralnog karaktera. ${ }^{33}$ Eventualno rešenje problema dvostrukog veta moglo bi se pronaći ako bi se uspostavio stalni dnevni red zasedanja, što bi onemogućilo upotrebu dvostrukog veta, te bi na taj način značajno ubrzali rad Saveta bezbednosti.

U stručnoj literaturi preovladava stav da u slučaju eventualnog proširenja broja članova Saveta bezbednosti nove stalne članice nikako ne bi smele dobiti pravo veta, jer bi na taj način postojala mogućnost dodatnog usporavanja rada Saveta bezbednosti. ${ }^{34}$ Interesantno je spomenuti i predlog grupe G4 koja se zalaže za reformu metoda rada Saveta bezbednosti koji smatraju da bi pitanje dodele veta novim članicama SB trebalo razmotriti na posebnoj konferenciji 15 godina nakon proširenja SB i promene Povelje UN. ${ }^{35}$

Interesantno je spomenuti i ideju koja se pojavila poslednjih godina o stalnom mestu EU u Savetu bezbednosti. Učešće EU u Ujedinjenim nacijama moglo bi se opravdati zbog sui generis pravne prirode Evropske unije, kao i trenutnog političkog i ekonomskog značaja ove organizacije na tlu Evrope i značajno bi doprinelo efikasnosti Saveta bezbednosti. Međutim, trenutno postoji puno prepreka koje onemogućavaju realizaciju ove ideje. Prema Povelji UN trenutno samo države, a ne i međunarodne organizacije, mogu biti članice UN. Međunarodne organizacije u okviru UN mogu imati samo status posmatrača. Još jedna ozbiljna prepreka članstvu EU u radu Saveta bezbednosti ogleda se $\mathrm{u}$ tome što još uvek u okviru EU ne postoji jedinstvena Zajednička i bezbedonosna politika svih članica, tako da je za sada nemoguće

${ }^{31}$ Georgia Papalia, "A Critique of the Unqualified Veto Power", op. cit., str. 59-60.

${ }^{32}$ Duško Dimitrijević, Reforma Saveta bezbednosti Ujedinjenih nacija, op. cit., str. 22-23.

${ }^{33}$ Ibid., str. 23-24.

${ }^{34}$ Slađana Mladenović „,Predlozi reforme Saveta bezbednosti Ujedinjenih nacija“, Politička revija, vol. 41, br. 3, Beograd, 2014, str. 39-59.

${ }^{35}$ General Assembly Fifty-ninth session, 6 July 2005, Internet: https:/ / www.auswaertigesamt.de/blob/231610/2c95f1f86406e1eac00a71d042f7c403/draft-resolution-g4data.pdf, 19/ 06/ 2020. Grupu "G4" formirali su potencijalni pretendenti za stalna mesta u Savetu bezbednosti: Nemačka, Japan, Indija i Brazil. 
očekivati da jedna članica $u$ debatama iznosi stavove i glasa $\mathrm{u}$ ime svih članica EU. ${ }^{36}$ Iako je cilj Nemačke, kao najmoćnije države u EU, stalno mesto ove organizacije u SB, ipak bi trebalo očekivati da prilikom eventualne buduće reforme SB i proširenja stalnih mesta Nemačka ima prednost $\mathrm{u}$ odnosu na bilo koju međunarodnu organizaciju.

Implementacija barem nekog od predloga za reformu upotrebe veta značajno bi doprinelo efikasnosti u radu Saveta bezbednosti. Međutim, mali su izgledi za adekvatnu upotrebe veta u skorije vreme ako uzmemo u obzir trenutne odnose među stalnim članicama.

\section{Značaj neformalnih sastanaka za reformu metoda rada Saveta bezbednosti}

Neformalni sastanci u radu Saveta bezbednosti počeli su da se održavaju početkom devedesetih godina prošlog veka, kada su stalne članice shvatile da je neophodno imati pouzdane podatke sa lica mesta kako bi moglo adekvatno da se reaguje na situacije koje ugrožavaju međunarodni mir. Prvi neformalni sastanak, koji se ticao situacije u bivšoj Jugoslaviji, održao je tadašnji predsedavajući SB Diego Aria (Diego Arria) koji je 1992. godine stalne članice upoznao sa svedočenjem uglednog pojedinca o situaciji u Bosni. ${ }^{37}$

Ovaj oblik sastanaka pokazao se vrlo korisnim, jer su se članicama SB mogli obratiti akteri koji nemaju mogućnost obraćanja redovnim putem, a imaju značajne informacije o pretnjama međunarodnom miru. S obzirom na to da sastanci "Arria-formule" nisu predviđeni Poveljom UN, ne postoji kruta pravila ko i pod kojim uslovima može učestvovati na ovim sastancima. Ovaj neformalni oblik delovanja SB saziva se na inicijativu jedne od članica Saveta bezbednosti, koja ujedno i predsedava sastankom. Sastanci neformalnog karaktera u prvom periodu korišćeni su za susrete članica SB sa predsednicima država, zato što su se Rusija i Velika Britanija protivile da na sastancima učestvuju predstavnici drugih organizacija. Prvi problemi o formi ovih sastanaka nastali su u jesen 1996. godine kada je čileanski ambasador Samovia

${ }^{36}$ Proces pristupanja Evropskoj uniji, koji se zasniva pre svega na usklađivanju nacionalnog zakonodavstva sa pravnim tekovinama Evropske unije, obuhvata i harmonizaciju nacionalne spoljne politike zemlje kandidata sa Zajedničkom spoljnom i bezbednosnom politikom EU. Detaljnije o Zajedničkoj spoljnoj i bezbedonosnoj politici EU vidi: Davorin Rudolf, „Zajednička sigurnosna i obrambena politika Europske unije prema Lisabonskom ugovoru", Zbornik radova Pravnog fakulteta u Splitu, br. 3, Split, 2014, str. 557-574.

${ }^{37}$ James Paul, Céline Nahory, Theses Towards a Democratic Reform of the UN Security Council, Global Policy, July 13 2005, Internet: https:/ / www.globalpolicy.org/securitycouncil/security-council-reform/transparency-including-working-methods-anddecisionmaking-process/41131.html?itemid=914, 10/06/2020. 
(Juan Somavía) hteo da u neformalne sastanke uključi i nevladine organizacije koje su se bavile pitanjima ljudskih prava. ${ }^{38}$ Ovaj predlog naišao je na ozbiljan otpor naročito od strane stalnih članica SB. ${ }^{39}$ Sukob je nastavljen i 1997. godine kada se pojavila ideja da se na ove sastanke kao učesnik pozove i Generalni sekretar Amnesti Internešnala (Amnesty International), a pošto je i dalje postojao jak otpor pronađeno je kompromisno rešenje da se sastanak održi na ad hoc osnovi. Konačno se 2000. godine stvorila povoljna politička klima u SB, naročito stav delegacije Velike Britanije da se i nevladine organizacije uključe u sastanke "Arria-formule" ${ }^{40}$ Iste godine dozvoljeno je i državama nečlanicama SB da na stalnoj osnovi prisustvuju u radu ovih sastanaka.

Značaj sastanaka ogleda se u tome što usled svog neformalnog karaktera omogućava iskrenu i privatnu razmenu mišljenja, $u$ fleksibilnom proceduralnom okviru bez obavezujućih odluka. ${ }^{41}$ Usled neformalnog karaktera sastanka o njima se do 2016. godine nisu vodili nikakvi zapisnici. Koristeći fleksibilnost ovog formata pregovaranja članice Ujedinjenih nacija uspele su da neka krucijalna pitanja, poput položaja osoba sa invaliditetom u oružanim sukobima ili bezbednosnim aspektima klimatskih promena, iznesu pred članice SB, iako nije postojao konsenzus da se o ovim pitanjima raspravlja na redovnim zasedanjima. ${ }^{42}$ Tokom 2016. godine u Savetu bezbednosti se kroz sastanke "Arria-formule" raspravljalo o položaju ranjivih grupa, naročito pripadnika verskih manjina i pripadnika LGBT populacije na ratnom području u Siriji. ${ }^{43}$ Od 2017. godine, države članice koje nisu u Savetu povremeno su se pridružile članovima SB u organizaciji sastanaka "Arria-formule".

Značajan korak ka reformi metoda rada SB predstavlja stav stalnih članica da sastanke "Arria-formule" koriste za bolju koordinaciju sa organizacijama civilnog sektora. U poslednje vreme ovi neformalni sastanci koriste se za konstruktivne dijaloge sa članovima Istražnih komisija Saveta za ljudska prava UN. Članice SB su se saglasile da predsednik SB dan pre sastanka utvrdi dnevni red i da zajedno sa Generalnim sekretarom ohrabruje učešće svih zainteresovanih aktera $u$ ovakvom vidu neformalne

\footnotetext{
${ }^{38}$ James Paul, The Formula Arria, Internet: https:/ / www.globalpolicy.org/component/ content/article/185-general/40088-the-arria-formula.html, 28/06/2020.

${ }^{39}$ Ibid.

${ }^{40}$ Ibid.

${ }^{41}$ Security council, Arria-Formula Meeting, Internet: https://www.securitycouncil report.org/ un-security-council-working-methods/arria-formula-meetings.php, pristupljeno: 13.06.2020.

42 Ibid.

${ }^{43}$ Jessica Stern, "The U.N. Security Council's Arria-Formula Meeting on Vulnerable Groups in Conflict: ISIL's Targeting of LGBTI Individuals", New York University Journal 186 of International Law and Politics, 48(4), 2016, pp. 1191-1198.
} 
komunikacije. Rezultati ovih sastanaka ostaju skriveni od očiju javnosti. Naročito su se neformalni sastanci održavali prilikom iznalaženja adekvatnog rešenja za sukobe u Siriji i Ukrajini. ${ }^{44}$

Sastanci "Arria-formule" mogli bi poslužiti za pripremanje nacrta rezolucija koje bi kasnije bile usvojene u Savetu bezbednosti. U dosadašnjoj istoriji uglavnom su stalne članice SB određivale sadržaj rezolucija koje bi se kasnije razmatrale i usvajale na sastancima Saveta bezbednosti. Tek, s vremena na vreme, pojavljivala se mogućnost da nestalne članice imaju značajniji uticaj na sadržinu rezolucija. Tako su npr. Australija i Luksemburg, kao nestalne članice SB, imale glavnu reč u izradi nacrta o humanitarnim rezolucijama Saveta bezbednosti u pogledu rata u Siriji 2014. godine. ${ }^{45}$ Neformalni sastanci "Arria-formule" poslednjih godina korišćeni su za konsultacije Generalnog sekretara UN sa predsednikom Generalne skupštine i predsedavajućim Saveta bezbednosti o značajnim pitanjima sa kojim se Ujedinjene nacije suočavaju.

Pored sastanaka takozvane „Arria-formule" u okviru Saveta bezbednosti pojavili su se i drugi oblici neformalne saradnje. Pre svega, treba spomenuti neformalni sastanak koji je održan tokom 1997. godine po "formuli Samovia“ ${ }^{46}$ Na ovom sastanku učestvovali su članovi Ekonomsko-socijalnog saveta UN kao i članovi drugog i trećeg komiteta Generalne skupštine UN. Raspravljalo se o humanitarnim pitanjima i izvršene su konsultacije sa pripadnicima Lekara bez granica. ${ }^{47}$

Nakon podizanja optužnice protiv tadašnjeg predsednika Sudana Bašira (Omar al-Bashir) pred Međunarodnim krivičnim sudom 2009. гоdine, Savet bezbednosti je bio pod pritiskom javnosti da zauzme zvaničan stav i razmotri ovo pitanje. ${ }^{48}$ Zbog protivljenja određenog broja članica došlo se do kompromisnog rešenja da se o ovom pitanju raspravlja $u$ okviru "Neformalnog interaktivnog dijaloga". Od tada do danas može se primetiti ekspanzija ovakvog vida debate u okviru Saveta bezbednosti. Ovo je vrlo zanimljiv način na koji je Savet bezbednosti uspeo da odgovori zahtevima današnjice i ne ponovi grešku s početka pedesetih godina prošlog veka, kada je usled suprotstavljenih interesa velikih sila propustio da adekvatno reaguje na ozbiljne pretnje međunarodnom miru. Tako se u okviru „Neformalnog

${ }^{44}$ Security council, Arria-Formula Meeting, op. cit.

${ }^{45}$ Center for UN Reform, The Accountability, Coherence and Transparency Group Better Working Methods for today'shttps://centerforunreform.org/wp-content/ uploads/2015/06/FACT-SHEET-ACT-June-2015.pdf, 15/06/2020.

${ }^{46}$ James Paul, The Formula Arria, op. cit.

${ }^{47}$ Ibid.

${ }^{48}$ Security council, Informal Interactive Dialogue, Internet: https://www.securitycouncil report.org/un-security-council-working-methods/informal-interactive-dialogue.php, 15/06/2020. 
interaktivnog dijaloga" razmatrala krizna situacija u Šri Lanki prouzrokovana delovanjem Tamilskih tigrova.

Neformalni interaktivni dijalozi bi se u budućnosti mogli koristiti da članice SB razmotre pitanja koja inače spadaju u nadležnost Generalne skupštine, a u perspektivi bi mogla predstavljati ozbiljnu opasnost po međunarodnu bezbednost. Na taj način bi se izbegle kritike, koje su se pojavile u poslednjoj deceniji od strane nekih članica Generalne skupštine, da Savet bezbednosti sve češće zadire u nadležnosti Generalne skupštine razmatrajući pitanja poput uticaja HIV-a i ebole na međunarodni mir, kao i problem nedostatka pitke vode na području afričkog kontinenta što prouzrokuje međunarodne sukobe, naročito na području basena jezera Čad. ${ }^{49}$

Izvesno bi se moglo očekivati da se u budućnosti na neformalnim sastancima ozbiljno razmotri pitanje karipskih država, koje se usled klimatskih promena suočavaju sa porastom vode, te bi u budućnosti mogle da potonu. ${ }^{50}$

Prilikom debate o reformi metoda rada Saveta bezbednosti francuska delegacija je predložila da "Neformalni interaktivni dijalog" postane stalna razmena mišljenja sa ostalim članicama Ujedinjenih nacija o pitanjima koja ih se tiču. ${ }^{51}$ Predlog Francuske naišao je na podršku velikog broja članica Generalne skupštine koje smatraju da će češći neformalni sastanci dovesti do veće transparentnosti u radu SB. Mnogi smatraju da neformalni oblici sastanaka i konsultacija predstavljaju ključan korak ka revitalizaciji metoda rada Saveta bezbednosti, pa i samih Ujedinjenih nacija. ${ }^{52}$ Neformalni sastanci bi trebali da doprinesu većoj transparentnosti koja trenutno nedostaje $u$ radu Saveta bezbednosti.

\section{Godišnji izveštaj Saveta bezbednosti}

U skladu sa Poveljom UN Savet bezbednosti ima obavezu podnošenja Generalnoj skupštini godišnjih izveštaja svojih aktivnosti. ${ }^{53} \mathrm{Za}$ vreme Hladnog rata godišnji izveštaji su podnošeni sa nekoliko godina zakašnjenja. U noti predsednika Saveta bezbednosti, od juna 1993. godine, članovi su se

${ }^{49}$ Ken Conca, The Security Council And Climate Change, December 6, 2017, Internet: https://sustainablesecurity.wordpress.com/2017/12/06/the-un-security-council-andclimate-change/, 20/6/2020.

${ }^{50}$ US Aid, Climate Risk Profile: Eastern and Southern Caribbean, February 2018, Internet: https:// www.climatelinks.org/sites/default/files/asset/document/2018-26Feb_CadmusCISF_Climate-Risk-Profile-ES-Caribbean.pdf, 06/07/2020.

${ }^{51}$ Ibid.

${ }^{52}$ James Paul, The Formula Arria, op. cit.

53 “UN Charter (1945)“, op. cit., Article 15. 
složili da izmene određene prakse koje se tiču godišnjeg izveštaja. Odlučeno je da nacrt godišnjeg izveštaja više ne treba smatrati poverljivim dokumentom do trenutka usvajanja, umesto toga biće dostupan zainteresovanim državama članicama pre usvajanja, koji će se održati na javnom sastanku ${ }^{54}$ Uprkos značajnim izmenama godišnji izveštaj SB i dalje je bio kritikovan od strane članica UN zbog nedovoljne transparentnosti. ${ }^{55}$ Kako bi se povećala transparentnost $\mathrm{SB}$ vremenom su se uz godišnje izjave počeli podnositi kratki izveštaji sa ocenama o radu ovog organa.

U okviru Generalne skupštine 2002. godine ponovo je pokrenuta debata na koji način poboljšati godišnji izveštaj SB. Nakon rasprave došlo je do saglasnosti $u$ pogledu sledećih pitanja: da se u budućim godišnjim izveštajima $u$ uvodu budu detaljno analizirani najvažniji trenuci u godini koja se razmatra, zatim da se nakon podnošenja godišnjih izveštaja analizira sposobnost SB da odgovori na situacije koje predstavljaju pretnju međunarodnoj bezbednosti, i na kraju bi se identifikovale poteškoće u očuvanju međunarodnog mira. ${ }^{56}$ Ideja je bila da sve članice (stalne i nestalne) SB učestvuju u izradi godišnjeg izveštaja. Iako je trebalo da predstavlja značajnu novinu u praksi, predlog uvoda godišnjeg izveštaja usvajan je na sednici bez adekvatne debate, tako da suštinski nije došlo do neophodne transparentnosti. Takođe, uvodni delovi godišnjih izveštaja su vremenom primetno bili predugački i izgubili su neophodnu notu analitičnosti. Osnovni problem je predstavljala činjenica da se i dalje u godišnjim izveštajima vrši puko nabrajanje aktivnosti bez adekvatne i podrobnije analize. ${ }^{57}$

Uz pozive na poboljšanje, pomoćno telo SB koje je odgovorno za većinu njegovih radnih metoda, neformalna radna grupa za dokumentaciju i druga proceduralna pitanja nastavila je da raspravlja o godišnjim izveštajima i uvela neke dalje izmene. Usvojeno je ograničenje dužine godišnjeg izveštaja Saveta bezbednosti i promenjen je period koji se razmatra u godišnjem izveštaju. Tako se od 2017. godine prešlo na kalendarski period godišnjeg izveštaja koji obuhvata period od 1. januara do 31. decembra, a ne kao dosad između dva redovna zasedanja Generalne skupštine..$^{58}$ Promena koja je uvedena na inicijativu Rusije i Litvanije pravdana je težnjom da se što bolje sagledaju godišnje aktivnosti. Uočljiv je problem da se još uvek godišnji izveštaji SB relativno kasno dostavljaju članicama $\mathrm{UN}$, i iz tog razloga one

54 “Note S/26015", President of Security Council, 30 June 1993.

${ }^{55}$ UN Security Council, Working Methods-Security Council Annual Report to the General Assembly, Internet: https://www.securitycouncilreport.org/un-security-councilworking-methods/annual-report-to-the-general-assembly.php, 14/07/2020.

56 "Note S/2002/199", the President of the Security Council, 22 May 2002.

${ }^{57}$ UN Security Council, Working Methods - Security Council Annual Report to the General Assembly, op. cit.

58 "Note S/2017/507", the President of the Security Council, 30 August 2017. 
nemaju dovoljno vremena da analiziraju izveštaje pre redovnog zasedanja Generalne skupštine, tako da se faktički države samo obaveštavaju o aktivnostima SB. ${ }^{59}$ Značajan korak napred ka poboljšanju metoda rada SB predstavljala bi promena čiji je cilj da se Generalna skupština, kao plenarni organ UN, ovlasti da usvoji godišnji izveštaj SB natpolovičnom ili kvalifikovanom većinom. Tada bi članice Saveta bezbednosti imale veću odgovornost prilikom donošenja odluka i prilikom sastavljanja godišnjih izveštaja. Eventualno neusvajanje izveštaja od strane Generalne skupštine proizvelo bi političku odgovornost naročito stalnih članica SB.

Bolji kvalitet godišnjih izveštaja o radu Saveta bezbednosti mogao bi se postići uspostavljanjem funkcije predsednika Saveta bezbednosti. Trenutno je Savet bezbednosti jedini organ $u$ okviru Ujedinjenih nacija koji nema predsednika već koristi sistem rotirajućeg predsedništva. Predsednik Saveta bezbednosti, čiji bi mandat trajao jednu ili dve godine, mogao bi bolje da sagleda aktivnosti SB što bi godišnji izveštaj učinilo sadržajnim i kvalitetnijim. Takođe, predsednik SB bi mogao u godišnjem izveštaju precizno da definiše ciljeve Saveta bezbednosti za sledeću godinu, što bi omogućilo lakše ocenjivanje uspešnosti delovanja Saveta bezbednosti. Još jedna prednost uspostavljanja funkcije predsednika SB ogledala bi se u kontinuitetu dnevnog rada, tako da bi se podrobno mogla razmotriti sva pitanja od međunarodnog značaja, a ne samo ona pitanja koja interesuju stalne članice. ${ }^{60}$

\section{Posete posmatračkih misija Saveta bezbednosti}

Savet bezbednosti je gostujuće (posmatračke) misije koristio kao fleksibilan oblik delovanja, prvenstveno namenjen posredovanju, preventivnoj diplomatiji i pružanju podrške mirovnim procesima. ${ }^{61}$ Prvi put je misija Saveta bezbednosti poslata 1964. godine na područje Kambodže i Vijetnama. Savet bezbednosti misije koristi u skladu sa širokim ovlašćenjima koja su mu dodeljena na osnovu Povelje UN. ${ }^{62}$ Svrha i zadaci misije zavise od slučaja do slučaja i određuje ih Savet bezbednosti. Primećuje se da je od kraja Hladnog rata značajno porastao broj misija koje uspostavlja Savet bezbednosti. Tokom poslednje decenije prošlog veka posete misija Saveta

${ }^{59}$ UN Security Council, Working Methods - Security Council Annual Report to the General Assembly, op. cit.

${ }^{60}$ Eduardo Vargas Toro, UN Security Council Reform: Unrealistic Proposals and Viable Reform Options", op. cit.

${ }^{61}$ Security council, Security Council Visiting Missions, Internet: https:/ / www.security councilreport.org/atf/cf/\%7B65BFCF9B-6D27-4E9C-8CD3-CF6E4FF96FF9\%7D/ working_methods_security_council_visiting_mission-12.pdf, 20/06/2020. 62 “UN Charter (1945)”, op. cit., Aricle 24. 
bezbednosti često su primenjivane na području Afrike, gde su postojale političke nestabilnosti i građanski ratovi. U praksi posmatračke misije su imale različitog uspeha. Tako se kao veoma uspešne posmatračke misije $u$ stručnoj literaturi navode misije na području Mozambika i Namibije, koje su nadgledale sprovođenje mirovnih sporazuma. ${ }^{63}$ Kao primeri neuspešnih posmatračkih misija navodi se posmatračka misija u Gruziji (UNOMIG) koja je trebala da nadzire prekid vatre i prati povratak interno raseljenih lica. Ova misija je obustavljena upotrebom veta Rusije 2009. godine. ${ }^{64}$ Interesantno je spomenuti i posetu misije Saveta bezbednosti koja je nadgledala sprovođenje referenduma o nezavisnosti Istočnog Timora od Indonezije. Poseta misije SB na području Kosova i Metohije 2000. godine je prva poseta u kojoj je učestvovalo svih 15 članica SB. ${ }^{65}$

Problematično je to što se posmatračke misije od strane UN šalju na područja gde su izvršene unilateralne akcije država, što može dovesti do tumačenja da su UN saglasne sa takvim akcijama, a što svakako utiče na kredibilitet UN i Saveta bezbednosti kao glavnog organa. Primeri koje možemo naći u praksi, a koji potvrđuju iznetu tezu, jesu uspostavljanje posmatračke misije na Kosovu i Metohiji, zatim u Avganistanu i Iraku, a sve nakon unilateralnih akcija NATO alijanse.

Veliki problem koji se uočava u stručnoj literaturi u vezi sa posetama misije SB, jeste da za razliku od prvobitnih izveštaja o situaciji na terenu koji su dostavljani na razmatranje odmah nakon povratka, danas to nije slučaj. ${ }^{66}$ U poslednje vreme od momenta uočavanja potrebe da se pošalje misija, do raspoređivanja misije i na kraju dostavljanja izveštaja prođe i do godinu dana. Članovi Saveta bezbednosti previše vremena gube dogovarajući se o sastavu misije, njenom vremenskom trajanju i ciljevima misije. Iz tog razloga može se zaključiti da ovaj oblik rada Saveta bezbednosti gubi na značaju, jer nije uspeo da zadrži preventivni element koji je bio karakterističan u početku. Broj poseta na godišnjem nivou poslednjih godina varira između pet i sedam, što govori u prilog činjenici da i pored uočenih nedostataka ovaj oblik rada Saveta bezbednosti zbog svoje fleksibilnosti ima značaj za održavanje međunarodnog mira i bezbednosti. ${ }^{67}$ Upravo iz ovih razloga neophodno je učiniti reformu posmatračkih misija kako bi se omogućilo brzo dostavljanje

${ }^{63}$ Maja Garb, "Evaluating the Succes of Peace Operations", Scientia Militaria, South African Journal of Military Studies, Vol 42, No 1, 2014, pp. 47-51.

${ }^{64} \mathrm{UN}$ news, Russia vetoes extension of UN mission in Georgia, 15 June 2009, Internet: https://news.un.org/en/story/2009/06/303512-russia-vetoes-extension-un-missiongeorgia, 01/09/2020.

${ }^{65}$ Security council, Security Council Visiting Missions, op. cit.

${ }^{66}$ Ibid.

${ }^{67}$ Ibid. 
informacija Savetu bezbednosti, što bi omogućilo adekvatno delovanje u očuvanju ili uspostavljanju međunarodnog mira.

\section{Uspostavljanje mirovnih misija}

Poseban oblik metoda rada Saveta bezbednosti jeste uspostavljanje mirovnih misija. Mirovne operacije nisu definisane Poveljom UN, već su se razvijale u skladu sa ciljevima UN da obezbede međunarodni mir. Osnov za uspostavljanje mirovnih misija najpre je nađen u članovima 33 i 34 Povelje UN koji regulišu sredstva mirnog rešavanja sporova koji mogu da ugroze međunarodni mir. ${ }^{6}$ Prema određenim mišljenjima pravni osnov za uspostavljanje mirovnih misija može se naći u članu 40 Povelje UN koji predviđa upotrebu privremenih mera, dok drugi ovo pitanje smatraju irelevantnim. ${ }^{69}$ Pronalaženja osnova za uspostavljanje mirovnih misija $u$ članu 40 je bez osnova, jer ovaj član nije moguće primeniti bez članova 39, 41 i $42 .{ }^{70}$ U stručnoj literaturi je moguće pronaći i stav da je osnov za uspostavljanje misije član 29 koji omogućava uspostavljanje pomoćnih organa SB. ${ }^{71}$ Zaključak koji se može izvesti iz ovih razmatranja jeste da u Povelji ne postoji nijedan član koji predviđa mogućnost uspostavljanja mirovnih misija koje bi sprovele mirovne operacije, već se one uspostavljaju na osnovu implicitnih ovlašćenja koja proizilaze iz Povelje UN. ${ }^{72}$ Mirovna misija se uspostavlja tako što Savet bezbednosti rezolucijom određuje mandat, veličinu i vremenski rok na koji se misija uspostavlja. Devedesetih godina došlo je do procvata mirovnih misija u okviru UN.

Da bi mirovna misija bila uspešna $u$ teoriji postoje različiti kriterijumi. Komandanti misije smatraju misiju uspešnom ukoliko prilikom obavljanja postavljenih zadataka nije bilo značajnijih žrtava, pritom ne obazirući se previše na rezultate misije. Ipak, u stručnoj javnosti preovladava stav da je neophodno da misija ispunjava određene uslove. Misija bi trebala da bude neutralna, da oružanu silu koristi u krajnjoj nuždi. ${ }^{73}$ Takođe da bi misija efikasno delovala neophodna je saglasnost zaraćenih strana i politička podrška za adekvatno delovanje. ${ }^{74}$ Od sukoba u Bosni mandati mirovnih

${ }^{68}$ Duško Dimitrijević, Reforma Saveta bezbednosti Ujedinjenih nacija, op. cit., str. 127.

${ }^{69}$ Christine Gray, International Law and the Use of Force, Oxford University Press, Oxford, 2008. p. 262.

${ }^{70}$ Duško Dimitrijević, Reforma Saveta bezbednosti Ujedinjenih nacija, op. cit., str. 128.

${ }^{71}$ Giad Draper, "The Legal Limitation upon the Employment of Weapons by United Nations Force in the Congo", Internationaland Comparative Law Quarterly, 1963, vol. 12, p. 392.

${ }^{72}$ Duško Dimitrijević, Reforma Saveta bezbednosti Ujedinjenih nacija, op. cit., str. 138.

${ }^{73}$ Maja Garb, "Evaluating the Success of Peace Operations", op. cit., pp. 47-51.

$192{ }^{74}$ Ibid. 
misija su drastično evoluirali. Članovi misije uglavnom više nisu neutralni već sarađuju sa državom u kojoj deluju na uspostavljanju i održavanju mira. Nije redak slučaj da se zadatak mirovne misije transformiše u skladu sa situacijom na terenu. Tako su se mirovne misije na području Hrvatske kretale od Zaštitnih snaga do vojno-posmatračke misije. ${ }^{75}$

Poslednjih godina pojavile su se ozbiljne kritike delotvornosti mirovnih misija. Kritike su kulminirale Brahimijevim (Lakhdar Brahimi) izveštajem u kome se tvrdi da je uspešnost mirovne misije UN usko povezana sa reformom metoda rada Saveta bezbednosti. ${ }^{76}$ Misije su postale ofanzivne i uglavnom se uspostavljaju bez saglasnosti države na čijoj teritoriji deluju, što je jedan od ključnih uzroka neuspešnosti misija u poslednje vreme. Problem neefikasnosti mirovnih misija ogleda se i u tome što dolazi do zakasnelog delovanja SB, te su uočljivi problemu u nejedinstvenom lancu komandovanja. ${ }^{77}$

Jedan od glavnih problema prilikom uspostavljanja mirovnih misija ogleda se $u$ nedovoljnoj komunikaciji između članica SB, Generalnog sekretara i članica UN koje ustupaju svoje vojne kontigente radi sprovođenja mirovnih misija. Najviše se zamera što članice UN ne učestvuju u izradi nacrta mandata mirovnih misija i što se ti nacrti dizajniranju na osnovu interesa samo tri države - Francuske, SAD i Velike Britanije. ${ }^{78}$ Upravo ovaj nedostatak kohezivnosti u upravljanju mirovnim misijama jedan je od glavnih argumenata tvrdnje da UN nisu više u mogućnosti da održe međunarodni mir. Nakon Brahimijevog izveštaja održan je sastanak u okviru Saveta bezbednosti na kome se raspravljalo o reformi uspostavljanja mirovnih misija. Glavni zaključak je bio da komunikacija između SB, Generalnog sekretara i članica UN koje učestvuju u mirovnim misijama nije na potrebnom nivou za adekvatno delovanje misija i da će se na tome intenzivno raditi u budućem periodu. ${ }^{79}$

$\mathrm{Na}$ sastanku 2014. godine Savet bezbednosti je prvi put razmatrao pitanje jedne zarazne bolesti poput ebole kao potencijalnu pretnju međunarodnom miru. Usvajanje rezolucije kojom se ova bolest smatra međunarodnom pretnjom pratilo je i raspoređivanje mirovne misije čiji je zadatak bio da pomogne u suzbijanju ove pošasti. ${ }^{80}$ Ovu misiju je finansirao

${ }^{75}$ Duško Dimitrijević, Reforma Saveta bezbednosti Ujedinjenih nacija, op. cit., str. 140.

${ }^{76}$ Rob de Rave, Rianne Siebenga, Timo Smit, Jaïr van der Lijn, Focused and adequate Security Council mandates, Clingendael Institute, 2017, pp. 14-15.

${ }^{77}$ Maja Garb, “Evaluating the Succes of Peace Operations”, op. cit., pp. 47-51.

${ }^{78}$ Rob de Rave, Rianne Siebenga, Timo Smit, Jaïr van der Lijn, Focused and adequate Security Council mandates, op. cit., pp. 7-10.

79 "United Nations, Security Council, Presidential Statement 26", Security Council 31 December 2015.

${ }^{80}$ Sebastian von Einsiedel, David M. Malone, Bruno Stagno Ugarte, "The UN Security Council in an Age of Great Power Rivalry", United Nations University Working Paper Series Number 04, New York, 2015, pp. 19-20. 
ogroman broj država, što govori u prilog činjenici da su prioriteti Saveta bezbednosti evoluirali.

Iako je broj mirovnih misija zbog ekonomske krize poslednjih godina značajno opao, uočava se da je Francuska među stalnim članicama Saveta bezbednosti najzainteresovanija za uspostavljanje mirovnih misija, naročito na afričkom kontinentu, pokušavajući na taj način da održi status velike sile. ${ }^{81}$ Primetno je da se SB isključivo bavi trenutnim međunarodnim sukobima potpuno zanemarujući prevenciju i sprečavanje novih sukoba. Kao primer uspešne mirovne misije, koja je imala preventivni karakter, može se navesti primer misije UN na području Severne Makedonije uspostavljene u periodu od 1992. do 1999. godine. Savet bezbednosti retko se odlučuje da preventivno reaguje iz razloga što Kina i Rusija sa određenom dozom sumnje gledaju na efekte prevencije, a i države koje su uključene u potencijalni sukob ne žele da se o njihovom problemu raspravlja na sednicama SB i da postanu predmet debate velikih sila, između ostalog i zbog stigmatizacije međunarodne javnosti. ${ }^{82}$

Nedostaci koji se uočavaju su da Savet bezbednosti uspostavljajući misiju ne uzima u obzir specifičnosti područja gde šalje misiju, zatim uputstva misije sadrže nedovoljne smernice, a ciljevi su nejasno određeni i ne znaju se prioriteti što dovodi do neadekvatnog finansiranja misije. ${ }^{83}$ Uočava se i problem nedovoljne saradnje i netransparentnosti SB sa Sekretarijatom UN i Generalnim sekretarom prilikom određivanja mandata misije. Poslednjih godina uspostavljene mirovne misije nisu adekvatno finansijski podržane, stalne članice Saveta bezbednosti previše pažnje posvećuju svojim interesima i nisu podjednako zainteresovane za uspostavljanje mirovnih misija. Reforma uspostavljanja mirovnih misija koja je neophodna trebala bi se kretati u pravcu da se Savet bezbednosti što više bavi prevencijom mogućih sukoba, zatim neophodna je bolja saradnja članica SB i Generalnog sekretara, naročito kada je $\mathrm{u}$ pitanju razmena informacija na terenu, i smernice $\mathrm{i}$ uputstva mandata mirovne misije bi trebala biti kratka i jasna sa konciznim određivanjem prioriteta misije. ${ }^{84}$ Neophodna je i tešnja saradnja Saveta bezbednosti sa drugim međunarodnim organizacijama koje pomažu u ostvarivanju ciljeva mirovne misije, kao što su NATO i EU, naročito ako se ima $u$ vidu da su mirovne akcije preduzete od strane regionalnih organizacija ocenjene kao vrlo efikasne.

\footnotetext{
${ }^{81}$ Ibid., pp. 3-4.

${ }^{82}$ Ibid., p. 9.

${ }^{83}$ Rob de Rave, Rianne Siebenga, Timo Smit, Jaïr van der Lijn, Focused and adequate Security Council mandates, op. cit., pp. 19-20.
}

$194{ }^{84}$ Ibid. 


\section{Zaključak}

Ukoliko se želi da Ujedinjene nacije ostanu sposobne da održe međunarodni mir neophodno je da se, pre svega, reformiše metod rada Saveta bezbednosti kao glavnog organa ove međunarodne organizacije. Pravci reforme bi trebali ići u pravcu ograničenja upotrebe veta, pošto se kroz istoriju pokazalo da mogućnost negativnog glasa stalnih članica SB dovodi do atrofiranosti rada. Treba ozbiljno razmotriti predloge da se onemogući upotreba veta kada se raspravlja o ozbiljnim kršenjima ljudskih prava i humanitarnih kriza.

Neformalni sastanci pokazuju sposobnost Saveta bezbednosti da se prilagodi izazovima današnjice. Značaj sastanaka "Arria-formule" i "Neformalnih interaktivnih dijaloga“, ogleda se u činjenici da se prilikom njihovog održavanja čuje stav i onih međunarodnih aktera koji inače ne bi imali pristup Savetu bezbednosti. Takođe, omogućavaju da stalne članice konstruktivno razmotre pitanja od međunarodnog značaja za koja ne postoji saglasnost da se razmotre na redovnim zasedanjima. Neformalni sastanci bi trebali da omoguće veću transparentnost u radu SB koja trenutno nedostaje. Ovaj oblik delovanja omogućuje neophodnu razmenu informacija i konsultovanje između SB i nevladinih organizacija koje imaju sve veći uticaj u međunarodnim odnosima.

Neophodno je nastaviti i reformu na godišnjim izveštajima koje Savet bezbednosti podnosi Generalnoj skupštini UN. Potrebno je nastaviti napore da se ovi izveštaji učine analitičkim i sadržajnim i omogućiti adekvatnu raspravu u Generalnoj skupštini o izveštaju. Samo na ovaj način će se uočiti nedostaci u delovanju Ujedinjenih nacija i preduzeti neophodne mere. Potrebno je da Savet bezbednosti uspostavi bolju koordinaciju sa drugim organima Ujedinjenih nacija.

Važan element reformisanja metoda rada Saveta bezbednosti obuhvata i reforma posmatračkih misija koje SB šalje u krizna područja. Da bi ove posete imale efekat bilo bi dobro da se zaključci misije o stanju stvari na terenu brže dostavljaju Savetu bezbednosti kako bi ovaj organ mogao adekvatno da deluje.

Što se tiče mirovnih misija koje uspostavlja SB, neophodno je uspostaviti bolju koordinaciju između Saveta bezbednosti, Generalnog sekretara i članica UN koje učestvuju u mirovnoj misiji. Takođe, neophodno je da mandati mirovnih misija imaju jasnije ciljeve i da se mandati izrađuju uz saradnju svih zainteresovanih aktera.

Delovanje u Savetu bezbednosti u budućnosti više bi trebalo biti okrenuto ka prevenciji, a ne čekati da se sukobi dogode, a potom se posvetiti saniranju posledica. Treba pronaći način da se stvori politička volja naročito među stalnim članicama SB, kako bi se sprovela efikasna reforma metoda rada koja bi omogućila da Savet bezbednosti ispuni svoju primarnu obavezu - a to je održavanje međunarodnog mira i bezbednosti. 


\section{Literatura}

Center for UN Reform, The Accountability, Coherence and Transparency Group, Better Working Methods for today's, Internet: https://center forunreform.org/wp-content/uploads/2015/06/FACT-SHEET-ACTJune-2015.pdf, 15/06/2020.

Conca, Ken, The Security Council And Climate Change, December 6, 2017, Internet: https:/ / sustainablesecurity.wordpress.com/2017/12/06/theun-security-council-and-climate-change/20/6/2020.

Dimitrijević, Duško, Reforma Saveta bezbednosti Ujedinjenih nacija, Institut za međunarodnu politiku i privredu, Beograd, 2009.

Draper, Giad, "The Legal Limitation upon the Employment of Weapons by United Nations Force in the Congo", Internationaland Comparative Law Quarterly, 1963, vol.12, pp. 387-413.

Einsiedel von, Sebastian, Malone, David, Ugarte, Bruno, Stagno, Ugarte, "The UN Security Council in an Age of Great Power Rivalry", United Nations University Working Paper Series Number 04, New York 2015, pp. 1-25.

Garb, Maja, "Evaluating the Succes of Peace Operations", Scientia Militaria, South African Journal of Military Studies, Vol 42, No 1, 2014, pp. 44-63.

General Assembly Fifty-ninth session 6 July 2005, https://www.auswaertigesamt.de/blob/231610/2c95f1f86406e1eac00a71d042f7c403/draftresolution-g4-data.pdf,19/ 06/ 2020.

Gordon, Nora, Pathways to Security Council Reform, Centar on International Cooperation, New York, 2014.

Gray, Christine, International Law and the Use of Force, Oxford University Press, Oxford, 2008.

Harrington, Joanna, "The Working Methods of the United Nations Security Council: Maintaining the Implementation of Change", International and Comparative Law Quarterly 66, no. 1, 2017, pp. 39-78.

Krivokapić, Boris, Međunarodno javno pravo, Institut za uporedno pravo, Pravni i poslovni fakultet, Beograd 2017.

Mladenović, Slađana „Predlozi reforme Saveta bezbednosti Ujedinjenih nacija“, Politička revija, vol 41, br. 3, Beograd, 2014, str. 39-59.

"Note S/26015", the President of Security Council, 30 June 1993.

"Note S/2002/199", the President of the Security Council, 22 May 2002.

"Note S/2017/507", the President of the Security Council, 30 August 2017.

Papalia, Georgia, "A Critique of the Unqualified Veto Power", Perth International Law, No. 2, Chicago, 2017, pp. 55-63.

Paul, James, Nahory, Céline, Theses Towards a Democratic Reform of the UN Security Council, Global Policy, July 13 2005, Internet: https:/ / www.global 
policy.org/security-council/security-council-reform/transparencyincluding-working-methods-and-decisionmaking-process/41131. html?itemid=914,10/06/2020.

Paul, James, The Formula Arria, Internet: https:/ / www.globalpolicy.org/ component/content/article/185-general/40088-the-arria-formula.html, 28/06/2020.

Prantl, Jochen, Krasno, E. Jean, Informal groups of Memeber states, in: Jean E. Krasno (ed.) The United Nations: Confronting the Challenges of a Global Society, Lynne Reiner Publishers, London, 2004, pp. 311-357.

Rave de, Rob, Siebenga, Rianne, Smit,Timo, Lijn van der, Jaïr, Focused and adequate Security Council mandates, Clingendael Institute, 2017.

"Resolution 267(III) (1949)", General Assembly of United Nations, 14 April 1949.

Rudolf, Davorin, „Zajednička sigurnosna i obrambena politika Europske unije prema Lisabonskom ugovoru", Zbornik radova Pravnog fakulteta u Splitu, br. 3, Split, 2014, str. 557-574.

Security council report - UN Security Council Working Methods, Internet: https:/ / www.securitycouncilreport.org/un-security-council-workingmethods/procedural-vote.php, 12/06/2020.

Security council, Arria-Formula Meetings, Internet: https://www.security councilreport.org/un-security-council-working-methods/arria-formulameetings.php 13/06/2020.

Security council, Informal Interactive Dialogue, Internet: https:/ / www.security councilreport.org/un-security-council-working-methods/informalinteractive-dialogue.php 15/06/2020.

Security council, report Security Council Visiting Missions, Internet: https://www.securitycouncilreport.org/atf/cf/\%7B65BFCF9B-6D274E9C-8CD3-CF6E4FF96FF9\%7D/working_methods_security_council_ visiting_mission-12.pdf, 20/06/2020.

Security Council, Veto, Internet: https://www.securitycouncilreport.org/ atf/cf/\%7B65BFCF9B-6D27-4E9C-8CD3-CF6E4FF96FF9\%7D/working _methods_veto.pdf, 12/06/2020, pp.1-20.

Security Council Working Methods, Security Council Annual Report to the General Assembly, Internet: https://www.securitycouncilreport.org/unsecurity-council-working-methods/annual-report-to-the-generalassembly.php, 14/07/2020.

Security council, The veto, Internet: https:/ / www.securitycouncilreport.org/ atf/cf/\%7B65BFCF9B-6D27-4E9C-8CD3-CF6E4FF96FF9\%7D/research_ report_3_the_veto_2015.pdf, 12/ 06/ 2020.pp.1-19. 
Sputnjik Srbija, Atak na rusko pravo veta u UN 114 država, $z a^{\prime}$, Internet: https:/ / rslat.sputniknews.com/rusija/201709231112769066-VetoRusija/, 11/06/2020.

Stern, Jessica, "The U.N. Security Council's Arria-Formula Meeting on Vulnerable Groups in Conflict: ISIL's Targeting of LGBTI Individuals", New York University Journal of International Law and Politics, 48(4), 2016, pp. 1191-1198.

The Accountability, Coherence and Transparency Group, Better Working Methods for today's UN Security Council. Presentation of the AC, Internet: https://centerforunreform.org/sites/default/files/Invitation\%20Launc h \% 20ACT \% 20-\% 202\% 20May \% 202013\%20-\%20Civil\%20society, $12 / 06 / 2020$.

Timofeitchev, Alexei, Conseil de sécurité de l'Onu: le droit de véto entre passé et avenir, 29 Sept. 2015, Internet, https://fr.rbth.com/international/ 2015/09/29/conseil-de-securite-de-lonu-le-droit-de-veto-entre-pase-etavenir_443869, 11/06/2020.

Toro Eduardo, Vargas, “UN Security Council Reform: Unrealistic Proposals and Viable Reform Options", American Diplomacy November 25, 2008. Internet: https://www.globalpolicy.org/security-council/securitycouncil-reform/transparency-including-working-methods-anddecisionmaking-process/41138.html?itemid=914, 13/07/2020.

“UN Charter (1945)", General Assembly of United Nations, 24 October 1945.

"United Nations, Security Council, Presidential Statement 26", Security Council, 31 December 2015.

UN news, Russia vetoes extension of UN mission in Georgia, 15 June 2009, Internet: https://news.un.org/en/story/2009/06/303512-russia-vetoesextension-un-mission-georgia, 01/09/2020.

US Aid, Climate Risk Profile: Eastern and Southern Caribbean, february 2018. Internet: https:/ / www.climatelinks.org/resources/climate-risk-profileeastern-and-southern-caribbean 06/07/2020. 


\section{ABSTRACT}

In this paper, the author deals with the issue of the reform of the working methods of the Security Council, considering it a key segment of the reform of the Security Council. Using the analytical method, the author examines the following issues that he considers crucial for efficient reform: the use of vetoes in the work of the Security Council, informal forms of meetings within the Security Council, the importance of the annual reports submitted by the Security Council to the UN General Assembly, the contribution of observation missions' visits, and the key issues of Security Council peacekeeping missions. The aim is to examine the current state of reforms, detect certain defects, and indicate the possible directions of change of the Security Council's working methods, in order for the principal organ of the United Nations to adequately respond to the future challenges.

Keywords: United Nations, Security Council, reform of the Security Council's working methods. 